\title{
Life Experiences in Parenting: The Perspective of Women with HIV-AIDS
}

\author{
Eka Ernawati*, Dewi Rahmawati, Indah Wulandari, Firda Afriyani \\ Department of Nursing, Universitas Faletehan, Serang, Banten, Indonesia
}

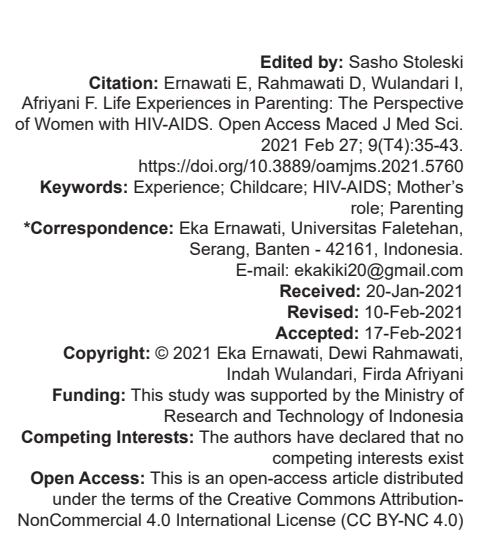

Introduction

Women with positive HIV status are at risk to fail in their role adaptation, causing confusion in carrying out multiple problems. The impact and problems caused by HIVIAIDS require treatment and support. As sufferers, mothers with HIV are at risk of experiencing problems either physically, psychologically, socially, and spiritually. From a physical perspective, HIV sufferers will experience health problems in the form of opportunistic infections due to decreased immunity, such as tuberculosis, candidiasis, and chronic diarrhea [1].

A decrease in physical function in general will have an impact on psychological well-being. Some of the psychological problems in wives with HIVIAIDS include shame, fear, and internal conflicts where wives with HIV have to close themselves off regarding their status, either to their children, their families or the social environment [2]. According to the results of research [3] housewives who suffer from HIV tend to keep their illness status a secret and are afraid to open up about their illness status to their children [4].

In the socio-economic aspect of the experience of HIV sufferers who experience stigma, according to
Kohan and Beigi [5], women with HIV who experience negative stigma from society can result in job loss. Problems in the spiritual aspect are also found when the process of accepting a disease fails. Spiritual distress occurs such as loss of hope, helplessness, and plans for suicide [6]. Cumulatively, the negative impacts mentioned above can worsen the quality of life in patients with HIVIAIDS [7].

The spread of HIVIAIDS in Banten Province continues to increase every year. This is influenced by several factors, such as the position of Banten Province, which is on the Java - Sumatra route, has an industrial area and international transportation facilities with a very high level of population mobility, resulting in changes in people's lifestyles. Some of the livelihoods of the people of Banten work in the Jakarta area. In addition, Banten Province is directly adjacent to two provinces with very high prevalence rates of HIVIAIDS cases, namely, DKI Jakarta Province and West Java Province [8].

The susceptibility to contracting a wife is caused by many things, one of which is the reluctance of a partner to tell other people (spouse/family) their status as a sufferer. Several studies have stated that the strong stigma of society, including family and partners toward HIV sufferers prevents patients from disclosing 
their HIV status to other parties [9]. Centers for Disease Control and Prevention [10] reported that women with HIVIAIDS are weak in making decisions regarding the management of their disease, decisions still have to be in accordance with family rules.

The condition of the partner's distrust has an impact on the task of family development. The family experiences conflict and the task of family development is cutoff. The rates of divorce and abandonment by spouses become family conflicts. The development task of being a single parent has an impact on childcare [11]. The impact that arises from physical, psychological, social, and spiritual aspects causes changes that occur in the family. These changes have an impact on changing the role of mothers.

The role of mothers as breadwinners in meeting the needs of their children as single parents changes in the role of the family, women become workers. This change is one of the problems in family life with HIV that requires a family-based approach in prevention, treatment, and care programs [12]. Research, it was found that a mother with HIV status is often unable to cope with the suffering she experiences, because based on her perception, she views that she does not receive support from people around her and tends to get a negative stigma. Mothers fail to adapt and apply good parenting to his children and tend to choose the type of permissiveness parenting.

Based on the above phenomena, it is important to deeply reveal the experiences of women with HIV/ AIDS in childcare in Serang Banten.

\section{Methods}

The research design used in the study was qualitative with a descriptive phenomenological approach. Phenomenological research demands an investigated picture of ordinary everyday experiences, a picture of things as experienced by people [13]. In this study, researchers revealed the experiences of mothers with HIV status in caring for children. Phenomenological design is a research method that has a contribution in terms of deepening the understanding of the behavior, actions, and ideas of each individual about the world of his life through a known and accepted point of view [14].

This research was conducted in the Serang Kota Health Center Work Area. Primary data requested came from Serang Kota Health Center, Banten Province. The sampling technique used purposive sampling with inclusion criteria in the form of women with HIV positive that has children, in a healthy condition, is able to communicate, and willing to be participants. In this study, researcher conducted a data collection process on seven participants as the predetermined inclusion criteria.
The number of the participants was seven people based on the saturation process, because the information generated by the seven participants was felt to be representative and the data saturation, recorder in an open place with a distance of $<50 \mathrm{~cm}$ from the participants. The instruments in qualitative research are the researchers. Researchers used semistructured interviews where the researcher made a list of questions in the interview guide that developed during the in-depth interview process. Researchers and research members are experienced in doing qualitative research. The ability of researchers to explore individual experiences is a competency that must be possessed.

In addition to the instrument, the researcher needs a field note format and a voice recorder. We used of a voice recorder to record the conversation between the researcher and the participants. Field note is used when the researcher observes nonverbal response from the participants during in-depth interview (record change expression, movement of limbs, eye contact, psychological response such as sadness, crying, anger, etc.). Researchers put the voice recorder in an open place with a distance of $<50$ $\mathrm{cm}$ from the participants.

We used phenomenological data analysis with Collaizi's approach, which aims to look the overview of women with HIV positive experiences in parenting. The process begun by reading the transcript repeatedly to find some significant statements, then to process the coding of the significant statements for preparing the categories. Furthermore, from the categories have similar meanings, research themes were formed. The final process was to describe the themes created and integrate them into a comprehensive description of the results to be revalidated by the participants.

To obtain the validity of the data, the researcher applied inspection techniques based on several criteria: (a) Credibility (prolonging engagement, triangulation, peer debriefing, and member checking), (b) transferability with strategies in the form of marking solid descriptions derived from the result of interview and field note contained in the data analysis table, (c) dependability using a trial audit strategy, and (d) confirmability by discussion to asking expert of qualitative research to read the result of the research and give assessment.

This study has received approval and permission from the research ethics committee. The proposed ethical procedure has received approval from the Tasikmalaya BTH StiKes Ethics commission with No. 017/KEPK-BTH/V/2020. After getting a statement of ethics, the researcher and the members prepared to collect data. This research was also carried out by considering the ethical principles of research by fulfilling The Five Right of Human Subjects in Research [13]. 


\section{Results}

\section{Participant demographic}

The number of participants who participated in this study is 7. Participants in this study used the $P$ code which was then used to replace the naming as well as describe the sequence of interviews that had been conducted in the form of P1, P2, P3, P4, P5, P6, and P7. Participants in this study ranged in age from 26 years to 56 years and had been People Living With HIVIAIDS (PLWHA) for more than 1 year. Participants were HIV patients managed by Serang Kota Health Center. The characteristics of this research are the participants who live in Banten, especially in the working area of the Serang Kota Community Health Center. All seven participants in this study were female. In-depth interviews with seven participants were conducted at the Serang Kota Health Center by previously explaining the aims and objectives of the researcher and providing an informed consent sheet as the participant's consent form. The characteristics of each of the main participants in this study will be described as follows (Table 1).

This section describes in detail the themes identified from the research results. The themes are grouped according to several categories (Table 2):

\section{Expectation of negative status in loved ones}

In this theme, there were three opinions about hope of the mother who is infected with HIV so that her child and her loved ones do not experience the same thing as her. The following is an excerpt from a participant:

\section{Hope the child is not infected}

HIV negative in children

"I feel relieved that my child is HIV negative and I still feel hopeful when my child is HIV negative" (P2).

"Alhamdulillah (thank God) my child is HIV negative" (P3).

Hope for the second child is HIV negative

"Yeah, I guess where else am I going. The important thing is that children don't get infected" (P7).

"Well, I do not know that I am a PLWHA, when I grow up, I find out when my child is older, my child is already grown up, already 5-years-old" (P4) "Checked here. There is no result. Alhamdulillah" (P7).

"I hope this is negative too, I told you to take the medicine so that the sides are also healthy" (P4).
The condition of the second husband was HIV negative

"With the second husband, told him to take medicine, told him to check, he also checked. Alhamdulillah, negative yeah" (P4)

\section{Lamentations of wives with PLWHA status}

\section{Family conflict}

The second theme shows the psychological condition of women's experiences as single fighter who have to struggle with HIV disease and life problems such as family conflicts, divorce, hiding their status from their life partners and dilemma off second marriage. This is illustrated in the statement of the participants as follows:

\section{Secret of the past}

"But when it comes to my husband's relationship with the first wife, don't reveal this, yeah, I'm afraid my husband will see" (P4).

Affair

"Only yes, there are those who say yes to my neighbors now, some are cheating, some are bringing high school children" (P4).

"Husband, because his association is not right, has been invited to do this with his friends" (P1).

\section{Desire for divorce and domestic violence}

"I had asked for a divorce many times, I was kicked out in the middle of the night too, by my husband because I asked for a relationship I didn't want, yeah, because in my mind where did he end up like that. (Indeed my husband is helpful, likes hitting like that)" (P4).

\section{Divorce}

"2008 was divorced from her first husband" (P6).

The second married

"Alhamdulillah, my child is HIV negative" (P3).

"Alhamdulillah, my children are both negative, thank God" (P5).

"2013 I met the husband of the two fathers" (P6).

\section{Single parent role}

"I feel I have to bear the heavy burden of life as a result of matchmaking from my parents" (P3). 
"I feel confused about my child's in the future and feel confused about how to raise my children" (P2).

"The husband's family does not understand the husband's condition, so they don't care" (P3).

"I have to act as a husband, mother, and child who have to take care of my mother who is blind" (P2).

"Mother has a soul since her husband's divorce, her soul is hard there with the child, it's hard to train, yeah, how do you do it for the child because the single percent was like that until now the mother is still selling" (P6).

\section{Replacing the role of head of the family}

In addition to being a single parent, several participants eventually replaced the role as head of the family, following the participant's expressions:

"Usually, we replace our male parents every day, right, no husbands, we have to be husbands. All the necessities must be done. Yes, we can work like that, yes selling" (P5).

"I work as a maid to support my family" (P2). "Well, being a single parent working hard, making his head legs, wearing glasses, after all, the head supports 3 children" (P6)

"Only the difference is a bit stubborn right now. The kids may test us. Isn't it true that the word is that orphans do work together" (P5).

\section{testing \\ Management of sick pediatric care and HIV}

The third themeappeared inalmostall participants regarding the management of sick children. This theme is derived from several statements of participants who seek to prevent HIV transmission to their children by doing screening and testing starting from pregnancy until child is born. Whereas in infected children, the effort made by a mother with HIV are positive by continuing to provide care for sick children and always hope for recovery for her beloved children but for other participants are confused with the treatment for the children and choose a protective in caring of their children. These phenomena are illustrated in the following statements:

\section{Maintenance Management of sick children}

\section{Care for sick children}

"I would like to tell you that my child who died was already in stage 3 . But not, Alhamdulillah Living at home, I care for a month there" (P4).

\section{Recovery of a sick child}

"The recovery is so February treated February March April the recovery period is the recovery period" (P6).
Hope for children's health

"Yeah just get used to the important thing is that the child doesn't get sick, it's really really sick" (P7).

\section{Get an HIV testing}

“I've been tested, I'm on my CD4 there, my son has only been tested once" (P2).

"My husband only checked it once" (P4).

"If I want it, it's been 2 years already. I just want to know, what about my current condition. Where have you been? Because I only tested it once" (P5).

"Yes, it must be an examination, it must be detailed. Because the mother is pregnant, he said HIV testing procedures for pregnant women" (P7).

"Confusion in the treatment of children, I just thought about the little child who got hit. Take the medicine, what do I say. I just got confused" (P7).

\section{Tendency of authoritarian and permissive} parenting in children

The fourth theme describes the sadness felt by the single mothers. The single mother with HIV positive who have to make decisions in implementing parenting styles for their children. Almost all participants apply permissive and authoritative parenting. Some participants feel that the condition of single parents with an illness makes them struggle to work.

Therefore, they often lose time to play so they often losing time to play and control their children's behavior and it is not uncommon for them to abuse children by scolding their children resulting in a deterrent effect on their children that cannot be avoided. Some participants also said that they even have to be independent of their children at an early age because there is no father's role in caring for them. The following is an excerpt from:

\section{Authoritarian parenting}

Fear of father

"I educate my children firmly and openly" (P1).

"I'm angry (laughs) at home, try it sis, clean up if you sweep it, don't play, just try to see Allah" (P7).

"My son is afraid of his father because he is often scolded" (P1).

Violence in parenting

"The father often flicks my child when the child doesn't want to be quiet" (P1). 
Concern in applied parenting

"I am afraid that my child will be mentally disturbed if he is often scolded" (P1).

"When my child is difficult to control, I always tell my children to obey, I am afraid that I will not come home" (P1).

\section{Early independence of children}

"Feeling sad because I have to teach my child to be independent at a young age, everything is completely alone" (P3).

"Children understand the responsibility that I give" (P1).

"It feels sad, I have to teach children to be independent, do everything alone" (P3).

"I discipline my children while educating them" (P1).

"Now we rarely take care of children, at most we think about snacking first" (P3).

"Children are told not to be ashamed to help their mothers to make a living by selling" (P1).

\section{Permissive parenting}

"I feel that I rarely take care of my child, because I have to make a living" (P3).

"My child tends to want to keep on playing the cellphone" (P1).

"My child's most frecuent activities are watching TV, playing with friends and playing cellphones" (P1).

"Sis, just playing the cellphone, "I've sat down and sat down. Just ok until evening. If I don't eat first, then eat. In the future, l'll just use the cellphone" (P7).

"Sometimes, it's sad. Sometimes we think the child is still little. Just trying to be strong" (P7).

\section{Discussion}

\section{loved ones \\ Expectation of HIV negative status of the}

The results show that the mothers wanted her children or husband to have HIV negative status. After being diagnosed, the mothers with HIV AIDS show feelings of shock, distrust, worry, fear, confusion, and anger then after some terminal symptoms appear another emotional response in the form of numbness, frustration, sadness, and depression [15].

The mothers with HIV have hope that they will stay healthy. The mother's hope is similar to that of her children and husband, so that. The hope that their children will be negative and do not experiences similar diseases as expressed by the fifth and seventh participants. When the child is declared negative, of course there is a feeling of happiness and less anxiety as expressed by P2, P3, and P4.

The women with HIV have hopes for themselves. One of the hopes they want is that they can continue to be in good health and be able to maintain their health status [16]. The status of single mother requires high level of activities in their daily lives. This becomes a self-motivation for women with HIV and AIDS. It becomes a strength that is owned to stay healthy and be able to carry out the daily activities [17].

There is an internal motivation of people with HIV and AIDS to survive and stay healthy becoming one of the reasons for the adherence of people with HIVIAIDS in undergoing treatment. One of the reasons for adherence to HIVIAIDS sufferers in undergoing treatment. With an optimistic attitude, people with HIVIAIDS are moved to increase enthusiasm to work, motivation to survive, and have more positive thoughts. Apart from the hope of being healthy, they also wish to be completely cured. The mothers with HIVIAIDS, although at the beginning of the diagnosis phase will face adversity, they still have strong hopes from within themselves and their surroundings. The hope for oneself is a healing medicine and a source of strength [17].

Mothers have another hope, namely children. Children are the main source of support for the participants. This is in line with the statements of all participants that they want their children not to become infected with HIV and to live like normal children. The participants have a commitment to continue to take care of their children's needs as best as possible by continuing to act as the head of the family who works to meet the needs of the family as well as to act as mothers, including trying to optimize the prevention of transmission during playing or interaction with children.

The participants in this study have a good commitment to their children, namely, during pregnancy by maintaining their pregnancy and keeping their pregnancy healthy and giving birth and trying to take good care of their children even though the participants have a positive HIV status. Despite of their condition, the participants are still committed to being able to take good care of their children like other mothers who do not suffer from HIV while preventing transmission when interacting with their children [18].

\section{Lamentations of wives with PLWHA status}

Wives with PLWHA status have complex psychological changes. The wife with the status of PLWHA in this study has a condition that laments the 
situation that happens to her. The lament expressed by the participants is included in the sub-themes. Subthemes that emerge are the state of the mother having a hidden past, experiencing infidelity, the desire to divorce and domestic violence, and dealing with the current secret of the husband's.

In the process of family development, they face various kinds of family conflicts in the form of lack of openness, domestic violence, and even divorce. The participants in this study experienced hidden dark past condition as well as their husband's past. The openness between partners does not occur during the family formation process. It results in the conflicts when developing the newly married couple's family [19]. In the process of family development, due to the absence of openness, domestic violence, infidelity, and even is often found as its impacts.

The problems start with infidelity and domestic violence ending in divorce. This condition makes the mothers feel psychologically hard and even fall into a state of depression. Research conducted [20] states that women with PLWHA experience depression because of the life burden they experience as a woman experiencing problems in the family, in addition to stigma and in his study, Arinze [19] stated that widows with HIV status experience pain, suffering, and inhuman public treatment.

Family conflicts experienced by the make the family situation incomplete and the family cycle is broken [11]. This condition forces the mothers as many as four participants to play the role of a single parent as a substitute for the head of the family, because the abandonment of the partner is experienced by the four participants. Family conflicts that occur in each couple are to need to adapt. Conflicts that occur between couples who have children need to be resolved immediately. It has impact on the social role of children. The adaptation affects the roles and responsibilities of parents in parenting [21].

Wives lament is felt by the participants, namely as a single parents. The mother's role as a single parent plays important family duties and responsibilities. The mother as works the breadwinner, caregiver for the sick, her children and herself. Therefore, a wife with HIVIAIDS status needs to have good self-management as single parents [22].

\section{HIV testing}

The Management of sick pediatric care and

The management of sick children being treated with HIV, the recovery process for illness is felt by P4 and P6 and the hope of always being healthy is desired by all participants. Children who experience illness make the mothers more protective and confusion occurs when the child is sick (P7). The (P7) complained about HIV testing process during pregnancy. The desire to always check for HIV is found in P2, P4, P7, and P5.
HIV infection in children is acquired in the mother's womb. HIV infection in children can develop into AIDS, the asymptomatic infections that are difficult to detect and opportunistic infections occur together when the immune system begins to decline [23]. The children get sick. When the child is treated, there is confusion. The mothers become more protective of her children. The sick children become stressors in themselves for mothers. The role of mothers to care for their children is increasing. The sick children can make their mothers experience fatigue and decrease endurance. Rahmaniyar research [18] stated that the role of the mother is needed when the child is sick. It requires the mothers to forces mothers to be able to pay attention to the children and families without thinking about their health conditions.

Family duties and responsibilities in caring for sick children are needed. The division of the roles of mother and father complements each other to meet the needs of sick children. A study by Halim [24] stated that family tasks for preschool age children require parental adaptation because roles are complex. The parents become busy with pre-school child development tasks. This task will be more complex when family members experience illness. It happens to in P4 and P6 who have preschool children.

The recovery process that occurs until the child is healthy requires a family role. The role and function of the mother will increase if the mother is a single parent. The mother has additional duties as the head of the family, breadwinner, and care giver for sick children [25].

HIV prevention can be taken by antenatal care. Pregnant women with HIV need to do early detection and prevention of their babies. However, in this P7 did not realize that she was infected so that there was a delay in the prevention [24]. The expectations of PLWHA are very dependent on health services, especially in diagnostic tests such as HIV testing or a check on the amount of virus in the blood.

\section{Tendency of authoritarian and permissive parenting in children}

Women are a group at risk and the most sensitive to HIVIAIDS transmission. This is due to the role of women as wives and also mothers of their children who will give birth to future generations [26]. Women, especially housewives, are at high risk of having HIV because they are powerless to protect themselves from their obligation to continue to serve their husbands and remain obedient. Considering that our culture still adheres to patriarchal principles. The culture and helplessness of women have led to the neglect of many cases of HIVIAIDS transmission to women from their husbands and the neglect of women's reproductive health rights. 
Mothers with HIV status, among others, will be faced with self-stigma, changing roles, especially for women whose husbands died. They have to deal with the dual role of the head of family who works hard to make a living. The mother also has to undergo routine medication for the rest of her life as well as acting as a mother who must raise and educate children without the assistance of a husband or father figure. It affects the mothers in implementing parenting styles for their children.

Parenting is an implementation of decisionmaking between couples regarding the process of child development, and child socialization aiming at raising children who are responsible and have a contribution to their social environment. Parenting cannot be separated from the role of mother or being mothers. Mothers have the role of providing education so that they can have good adaptations and achieve competence in social interactions [12].

There are several parenting styles that are widely applied by parents including: Authoritarian or coercive parenting which is a warm but demanding type of parenting. Parents who apply this parenting style tend to be discipline make strict rules, often restrict their, often apply prohibitions, give punishment in emphasizing the value of obedience and expect rules to be obeyed without any explanation. Children who get this parenting style tend to be rebellious, and highly dependent, they become easily insecure, worried, they become easily self-confidence, low levels of selfesteem, and high levels of depression [15], [27].

The next parenting style is permissive parenting. This parenting style provides broad freedom for their children. The impact of the application of this parenting style is that the children will be low in extrinsic motivational orientation in terms of school activities or in relationships, especially in youth groups. It is because the parents in this parenting style are often not directly emotionally involved in their child's life. Children do not have self-control in their actions because parents often agree with all the demands and requests of their children. All family life seems to be very much determined by the requests and desires of the children [28].

In this study, it is found that participants tend to apply permissive parenting to their children, It is revealed that after being diagnosed with HIVIAIDS, they experience in the form of reduced intensity and harmony with children, she revealed that those who currently pay more attention to their children are their grandparents, while they give less attention to their children. The mothers become passive in providing care for children [12]. The main factors are physical fatigue of the mothers and psychological burden [29].

Mothers who have physical exhaustion until there is a decrease in body resistance will have an effect on their ability to play their role optimally, especially in caring for children. This has an impact on his limitations in performing the role that should be carried out optimally [12], [30]. The mothers have a dual role as a result of losing a partner. Therefore, parenting done by providing opportunities, playing together, and affection is limited [31].

In addition, the consideration of parents, especially mothers in applying permissive parenting with the consideration of the seven participants, shows that there are four participants who have children under five and preschool category. The age of a young child is a consideration for mothers to give children freedom to play because children cannot be given much advice. Another factor is the condition of the children who has an insecure attachment with his grandmother or grandfather or people around him who always spoil them. The condition of a failed marriage is also a cause the mother has a husband with HIV positive status but is physically limited so that she cannot support the family. Having less financial condition supports, the participants become more focused on meeting the children's needs physically (providing the needs to eat, snacks, and school for the children). Therefore, it results in more freedom and less rules for children.

In this study, it is also found authoritarian type of parenting. As P1 and P7 educate their children firmly with various rules, they also often give punishment either physically (by flicking) or verbally by yelling at or scolding their children. The decision was made because of the concerns about the children's situation and the hope to avoid their child to experience the same thing. Thus, the mothers tend to make restrictions for the children, provide punishment, respond with anger if the child makes a mistake, and demands that the child always obey what the participants say as parents.

A study Karina [12] found that female participants who are unable to cope with psychological stress due to illness and also the burden of life will make themselves make negative coping decisions and have an impact on the emergence of hopeless conditions. The participants like to show a coercion attitude in the form of communicating with the children in loud tones, yelling at the children so that the children are frightened and which have a deterrent effect and tends to follow the mothers orders. In addition, the participants will also use the love withdrawal technique which will use a form of threat to children in the form of leaving the children if the children bad behavior has not changed.

The third participant said that there is a regret when the children must have hard life and be independent at an early age. She revealed that her children become more difficult to manage. There is a mental worry of the children who tend to be scolded often. Even one of the children of P1 expressed his fear of his parents, namely, his father because he is often scolded. This of course will have an impact on the children's emotional development in the future. These results are in accordance with the research of Lee [32] that the parenting style will have a significant effect on emotional intelligence and the formation of children's 
Table 1: Characteristics of main participants

\begin{tabular}{llllll}
\hline Initial & Age (Th) & Work & $\begin{array}{l}\text { Source of } \\
\text { transmission }\end{array}$ & $\begin{array}{l}\text { Suffering duration } \\
\text { from HIV }\end{array}$ & $\begin{array}{l}\text { Duration of } \\
\text { treatment }\end{array}$ \\
\hline (P1) & 56 Years & Not employed & Husband & 5 Years & 5 Years \\
(P2) & 39 Years & Not employed & Husband & 3 Years & 3 Years \\
(P3) & 26 Years & Not employed & Husband & 7 Years & 7 Years \\
(P4) & 29 Years & Not employed & Husband & 6 Years & 6 Years \\
(P5) & 28 Years & Not employed & Husband & 3 Years & 3 Years \\
(P6) & 26 Years & Not employed & Husband & 2 Years & 2 Years \\
(P7) & 45 Years & General & Husband & 2 Years & 2 Years \\
& & employees & & & \\
\hline
\end{tabular}

behavior. The parenting style of parents with HIV positive status in Thailand with a typical overprotective of children with HIV positive status will also shape them to become individuals with low self-esteem, and selfconfidence that is less proven when the children are able to express their complaints.

Table 2: The theme of the interview results

\begin{tabular}{ll}
\hline Theme & Sub themes \\
\hline $\begin{array}{l}\text { Expectation of negative } \\
\text { status in loved ones }\end{array}$ & $\begin{array}{l}\text { The hopes of children and husbands are not } \\
\text { infected }\end{array}$ \\
$\begin{array}{l}\text { Lamentations of wives } \\
\text { with people living with }\end{array}$ & $\begin{array}{l}\text { Family conflict } \\
\text { ChVIVIDS status }\end{array}$ \\
$\begin{array}{l}\text { The management of sick } \\
\text { child care and HIV testing }\end{array}$ & Sick child care management \\
& Drug management and medication \\
Tendencies of & HIV testing \\
authoritarian and & Authoritarian parenting \\
permissive parenting in & Worry \\
children & Early independence of children \\
& Permissive parenting \\
\hline
\end{tabular}

However, the positive side of the authoritarian parenting style is based on the interviews with participants. The results show that P1 felt that the benefits of being independent from childhood would be felt when the children have become adults because they have already understood and are not ashamed to live their life and even help their parents to work to meet their daily needs. The independence instilled by P1 in their children since childhood is their provision to be strong in facing life's challenges.

The description of different parenting styles explains that the parenting styles taken by especially in the formation of children's emotional characteristics. We cannot view the parenting patterns only from the negative. However, parenting can also have its positive impacts depending on the goals, time, and the ways of parents in applying it. In the last phase, the participants succeed in interpreting the sick condition and their role as mothers in a positive way. The participants' appreciation of the meaning of illness which is a gift from God allows them to accept their destiny sincerely. The partispan believes that God will always protect them and the children. The subject places themselves as a role model for children. Due to this reason, the participants will be very eager to give their best for their children. The participants will be very eager to give everything to the maximum for their children. Emotionally stable conditions have a major influence on the quality of warmth and sensitivity shown by mothers to their children. The participants can still maintain the attachment with their children by continuously build warm communication. The participants also seek to understand the needs of their children and strive to meet them.

\section{Conclusion}

This research was qualitative research with a phenomenological approach. The results of this study reveal new things that were not found from the results of previous studies in the form of expectations of HIV negative status of the loved ones, the lamentation of wives with PLWHA status, the management of the sick children care and HIV testing, and the tendency of having authoritarian and permissive parenting in children. Therefore, it is important to increase peer group counseling on the process of disease acceptance, the management of sick children management, and the implementation of HIV testing that can be accessed by every member of the PLHIV families. Similarly, the study also finds the importance of designing parenting patterns for children to match their needs, parenting goals, and goals that parents want to achieve for their children in the future. As well as the importance of designing parenting patterns for children to match their needs, parenting goals, and goals that parents want to achieve for their children in the future so that there is no developmental delay or deviant behavior that occurs in children in the future.

\section{Acknowledgments}

We would like to appreciate the participants of Puskesmas (Public Health Center) Serang Kota. This research is sponsored by The Ministry of Research and Technology of Indonesia.

\section{References}

1. Bare S. Brunner and Sddarth's Textbook of Medical-surgical Nursing. $12^{\text {th }}$ ed. Alphen aan den Rijn: Wolters Kluwer; 2010.

2. Gillard MA, Roark F. Support for basic psychological needs in the context of HIV disclosure for older you children and youth. Serv Rev. 2013;35:102-11. https://doi.org/10.1016/j. childyouth.2012.10.021

3. Waluh NR. Mother Living with HIV Disease: A Grounded Theory. Doctoral Dessertation from Proquest LLC. UMI 330192; 2008.

4. Nyamathi A, Ekstrand M, Zolt-Gilburne J, Ginguly K, Sinha S, Ramakrishnan P. Correlates of stigma among rural Indian women living with HIVIAIDS. AIDS and behavior correlates of stigma among Rural Indian women living with HIVIAIDS. AIDS and behavior. AIDS Vehavior. 2013;17(1):329-39. https://doi. 
org/10.1007/s10461-011-0041-9

PMid:21915715

5. Kohan N, Beigi M. HIV positive women's living experiences. IJNMR 2007;13(4):155-6.

6. Majumdar B. An exploration of socioeconomic, spiritual, and family support among HIV-positive women in India. J Assoc Nurses AIDS Care. 2004;15(3):37-46. https://doi. org/10.1177/1055329003261967

PMid: 15165374

7. Haroen WC. Quality of life in women with HIVIAIDS and women with partner has HIVIAIDS in West Java, Indonesia. Univ Indones. 2008;10(18):1-13.

8. Serang KP. Laporan Quartal 15 GF (Global Found). Fase 2. Kabupaten Serang; 2014.

9. Thomas S, Nyamathi B, Swaminathan A. Impact of HIVIAIDS on mothers in Southern India: A qualitative study. AIDS Behav. 2009;13:989-96. https://doi.org/10.1007/s10461-008-9478-x

10. Centers for Disease Control and Prevention. HIV-AIDS among Women Resources Women Topics. Atlanta, Georgia: Centers for Disease Control and Prevention; 2015.

11. Ernawati, E., Rahayu, S.Y. and Kurniawan, T., 2019. Life Experiences of Women (Housewives) Diagnosed Hiv-Aids in Serang. KnE Life Sciences, pp.272-283.

12. Karina H. Memahami Pola Asuh Pada lbu yang Terinfeksi Human Immunodeficiency Virus; 2009.

13. Polit DF, Polit-O'Hara S, Hungler BP. Essentials of Nursing Research: Methods, Apraisal, and Utilizations. $6^{\text {th }}$ ed. Philadelphia, PA: Lippincot, William and Wilkins; 2010.

14. Afiyanti. Metodologi Penelitian Kualitatif dalam Riset Keperawatan. Jakarta: PT Raja Grafindo Persada; 2014.

15. Rokhmah, D., 2015. Pola asuh dan pembentukan perilaku seksual berisiko terhadap HIVIAIDS pada waria. KEMAS: Jurnal Kesehatan Masyarakat, 11(1), pp.125-134. https://doi. org/10.15294/kemas.v11i1.3617

16. Utami. Konsep Diri Wanita Dengan Hiv Dan Aids Di Kota Makassar Tahun; 2017.

17. Safitri. Pengalaman Perempuan Dengan HIVIAIDS Dalam Menjalani Pengobatan. Vol. 2. Safitri; 2015. p. 9.

18. Indriastuti. Faktor-faktor yang Mempengaruhi Pencapaian Peran sebagai Ibu pada Perempuan dengan HIVIAIDS di Yogyakarta Factors that Affect Maternal Role Attainment in Women with HIVIAIDS in Yogyakarta. Vol. 15. Yogyakarta: Indriastuti; 2015. p. 75-83. https://doi.org/10.30597/mkmi.v15i4.7931

19. Arinze UC. The widow in South-East of Nigeria in Legal and customary turbulence: Need for mandatory paradigm shift. Int $\mathrm{J}$ Res Dev. 2011;8(1):1-14.
20. Bhirawa MA. Depression Description in Women PLWHA Lives in Jakarta. J Perkota. 2016; 8 (2): 94-117. https://doi.org/10.25170/ perkotaan.v8i2.278

21. Rahmaniyar RI, Rudhiati F . Phenomenologica Studies: Nursing Needs Families of HIV-Aids Children in Indramayu Regency. PIN-LITAMAS. 2018;1(1):258-65.

22. Webel AR, Higgins PA. The relationship between social roles and self-management behavior in women living with HIVIAIDS. Women's Health Issues. 2012 Jan 1;22(1):e27-33.

23. Evalina, R., 2016. A descriptive study of HIV infection in children in General Hospital Center Adam Malik Medan. Sari Pediatri, 14(2), pp.73-8. https://doi.org/10.14238/sp14.2.2012.73-8

24. Halim, Y., Syamsulhuda, B.M. and Kusumawati, A., 2016. Behavior-Related Factors Pregnant Women in HIV Examination in Public Health Center Work Areas Halmahera Semarang City. J Community Health. (Undip), 4(5), pp.395-405. https://doi. org/10.14710/jpki.12.1.115-133

25. Siswanto, F.K., 2017. Implementation of Protection of the Rights of Children with Patients HIV / AIDS. Legal Perspective, 15(2), pp.238-250.

26. Nyblade L, Field ML. Women, Communities, and the Prevention of Mother-to-Child Transmission of HIV: Issues and Findings from Community Research in Botswana and Zambia. Washington, DC: The International Center for Research on Women; 2000.

27. Milevsky SN. Maternal and paternal parenting styles in adolescents: Associations with self-esteem, depression and life-satisfaction. J Child Fam Stud. 2007;16:39-47. https://doi. org/10.1007/s10826-006-9066-5

28. Dariyo A. Psikologi Perkembangan Anak Tiga Tahun Pertama. Bandung: Refika Aditama; 2011.

29. Schuft L, Duval E, Thomas J, Ferez S. To be or not to be sick and tired: Managing the visibility of HIV and HIV-related fatigue. Health (London). 2018;22(4):317-36. https://doi. org/10.1177/1363459317693406 PMid:28401815

30. Handayani I. Pengalaman injecting drug users living with HIV/ AIDS menjalani terapi antiretrovial. J Keperawatan Indones. 2012;15(2):103-8. https://doi.org/10.7454/jki.v15i2.34

31. Murphy M, Roberts DA, K. J, Herbeck D. HIV disease impact on mothers: What they miss during their children's developmental years. J Child Fam Stud. 2011;20(3):361-9. https://doi. org/10.1007/s10826-010-9400-9

PMid:21637348

32. Lee LL. Parenting styles and emotional intelligence of HIV affected children in Thailand AIDS Care. 2012;25(12):1536-43. https://doi.org/10.1080/09540121.2013.793264

PMid:23651471 